\title{
NIEMIECKOJĘZYCZNY ODBIÓR TEKSTÓW JULIANA TUWIMA KILKA UWAG O TRUDNOŚCIACH TRANSLACYJNYCH
}

\section{SŁOWA KLUCZOWE}

Julian Tuwim; poezja; recepcja niemieckojęzyczna; przekład

Rozważając problem deficytów recepcji utworów Tuwima na obszarze niemieckojęzycznym, nie sposób nie odnieść się do trudności związanych z tłumaczeniem tych semantycznie i lingwistycznie skomplikowanych konstruktów tekstowych ${ }^{1}$.

Julian Tuwim należy do grupy autorów, których genialność i kunszt poetycki przysparzają wiele trudności osobom podejmującym próby tłumaczenia, a przez to i interpretacji konkretnych tekstów. Z jednej strony, przyczynę tych problemów stanowią treści, kryjące w sobie liczne dygresje literackie i historyczne, wymagające od czytelnika nie tylko znacznych kompetencji dotyczących teorii i historii literatury polskiej, ale również znajomości realiów historycznych i politycznych okresu Tuwimowi współczesnego (choćby po to, żeby dostatecznie trafnie interpretować jego upodobanie do specyficznej satyry i groteski, odnoszących się w dużej mierze do wydarzeń jemu współczesnych) oraz zrozumienia zagadnień związanych z tożsamością autora czy też kwestią jego emigracji. Z drugiej strony, kłopoty rodzi język poetycki Tuwima, czyli zarówno skomplikowana warstwa werbalna jego tekstów i mistrzowskie posługiwanie się przez poetę

Jolanta Doschek - dr, Institut für Slawistik, Universität Wien, Spitalgasse 2, Hof 3, 1090 Wien, Österreich; e-mail: jolanta.doschek@univie.ac.at; https://orcid.org/0000-0003-1336-2791.

1 W tym artykule tylko wycinkowo przyglądam się problemom translacyjnym, jakie rodzi poezja Juliana Tuwima przekładana na język niemiecki. Inny aspekt poruszanego zagadnienia prezentuję w osobnym tekście, częściowo zarazem odwołując się w nim do ogólnych ustaleń, które prezentuję również w niniejszej analizie (zob. Doschek 2017). 
słowem, fantastycznym i prawie mistycznym, nieznanym jeszcze w takiej formie współczesnemu mu odbiorcy, które poeta nieustannie i niestrudzenie doskonali, jak i jego upodobania słowotwórcze - Tuwimowskie „fantazje słowotwórcze”, jak je nazwał Jan Zygmunt Jakubowski (Jakubowski 1954: 10). Nic dziwnego, że teksty Tuwima stanowią ogromne wyzwanie dla tłumaczy. Teza wygłoszona przez Waltera Benjamina, że tłumaczenie poezji zawsze mija się z oryginałem i jej przekład jest niemożliwy (zob. Paepcke 1989: 5), w przypadku tych utworów nabiera namacalnego kształtu i dogłębnego sensu. Zaakceptowanie tej tezy byłoby, naturalnie, sporym i niedopuszczalnym uproszczeniem w odniesieniu do problematyki przekładu, którego jedną z podstawowych zasad jest jak najwierniejsze oddanie sensu, jaki niesie w sobie tłumaczony tekst, co wymaga od tłumacza często kreatywnej pracy twórczej po to, by stworzyć przekład wierny oryginałowi.

Nie będzie niczym nowym i szczególnym obserwacja, że teksty napisane przez autorów o silnie zindywidualizowanym języku są wyjątkowo trudne do przetłumaczenia, zwłaszcza jeśli jest to język, który powstał i posłużył tylko do napisania konkretnego dzieła. Dość często, dzieje się tak też w przypadku tekstów Tuwima, musimy zdefiniować problemy związane z odpowiednim zrozumieniem i interpretacją tekstu tłumaczonego, będącego swoistym systemem istniejącym i ukonstytuowanym wyłącznie w kontekście znaczenia tekstu obcojęzycznego, a tłumaczenie należy traktować jako proces, w którym tłumacz odbiera znaki i reaguje na nie znaczeniem przekazywanym dalej znowu pod postacią znaków (już Roman Jakobson mówił przecież o sferze znaków i sferze znaczeń, w których to dochodzi do przekazu znaków przy równoczesnej próbie odpowiedniego przekazu znaczeń). Podczas tłumaczenia tekstów obcojęzycznych wymagany jest dokładny przekaz znaków w celu wypełnienia funkcji komunikacyjnej tekstu. W przypadku tekstów literackich proces ten często okazuje się jednak nieadekwatny, a jego efekty bywają niejednoznaczne.

Nierzadko tłumacz zostaje zmuszony do wprowadzania kreatywnych zmian tekstu w miejscach, w których znaki języka docelowego nie są zgodne ze znakami języka tekstu wyjściowego. W teorii tłumaczenia mówi się w takiej sytuacji o tłumaczeniu kreatywnym (zob. Kußmaul 2000) - dzięki niemu istnieje możliwość przybliżenia zagranicznym odbiorcom treści dla nich niezrozumiałych, które powstały w wyniku nawet najbardziej poprawnego tłumaczenia eksplikatywnego, oddającego wprawdzie sferę pojęć, ale zatracającego otwartość semantyczną przekazu tekstowego. Tłumaczenie ma za zadanie ułatwić poprawną recepcję danego tekstu i jest ono swoistym medium ułatwiającym (umożliwiającym!) komunikację między autorem a obcojęzycznym odbiorcą jego dzieła. Własny styl pisarza, wybór wielu możliwych środków językowych, konstrukcja składniowa, odbiegająca często od narzuconych norm językowych, a także zastępowanie 
„normalnych konstrukcji” głównie po to, by przeciwstawić się zbyt częstemu ich użyciu - wszystkie te właściwości, charakteryzujące twórczość Juliana Tuwima, stanowią ogromne wyzwanie dla tłumacza, pośredniczącego w komunikacji między tekstami poety a ich zagranicznym odbiorcą. Pisarzowi podczas procesu twórczego chodziło głównie o: „znalezienie takich środków wyrazu, dzięki którym język najmniej kłamałby myślom, a wizja poetycka, przeżycie liryczne byłyby adekwatnie i jak najpiękniej przekazane czytelnikowi” (Sinielnikoff 1968: 3).

Przy poszukiwaniu najbardziej adekwatnego przekazu i środka wyrazu stosował Tuwim, jak już to zostało powiedziane, różne, bardziej lub mniej konwencjonalne, chwyty poetyckie. Sięgał m.in. po pewne typy konstrukcji kauzalnych, rzadko spotykane w mowie współczesnej albo nawet niespotykane wcale, jak na przykład różne formy narzędnika, charakteryzujące styl pisarski autora. O fenomenie stosowania przez Tuwima tych form (jak zresztą i o innych osobliwych funkcjach przypadków u autora Kwiatów polskich) pisała Roxana Sinielnikoff, analizując utwory poety pod kątem ich języka (Sinielnikoff 1968: 30-78). Jej opracowanie to kolejny dowód potwierdzający kunszt pisarski Tuwima, autora stale poszukującego inności i oryginalności, wytrwale pracującego nad interesującą i niespotykaną treścią, a zarazem formą utworu. Szczególny język poetycki tekstów Tuwima to wyzwanie dla odbiorców. Konstrukcje wprowadzane przez poetę prowadzą do odautomatyzowania recepcji, do aktywnego odbioru jego utworów, co nawet dla polskiego czytelnika nie jest sprawą łatwą, a praca nad ich obcojęzycznym przekładem staje się z tego powodu szczególnie utrudniona.

Roxana Sinielnikoff wymienia w swojej analizie cztery formy narzędnika: tautologiczny, sposobu, sposobu porównawczy i czynnika. Odpowiedni do zobrazowania dotychczasowych wywodów wydaje się narzędnik sposobu porównawczy - we współczesnej polszczyźnie rzadko występująca forma wypowiedzi, którą Tuwim wyjątkowo często wprowadzał do swoich utworów. Spójrzmy na dwa poniższe wyrażenia, które obrazują różnicę pomiędzy narzędnikiem sposobu a narzędnikiem sposobu porównawczym:

1. narzędnik sposobu: „iść kołem” (iść, zataczając koło)

2. narzędnik sposobu porównawczy: „kołem się toczyć” (toczyć się jak koło)

(Sinielnikoff 1968: 57).

W utworach Tuwima występują trzy rodzaje narzędnika sposobu porównawczego - narzędnik określający orzeczenie, określający podmiot i narzędnik postaci. Różnica pomiędzy tymi rodzajami to głównie inne znaczenie zwrotu w zależności od kontekstu, ale też i zmiana funkcji gramatycznej tego przypadka (Sinielnikoff 1968: 59). 
Główny problem podczas tłumaczenia takich form gramatycznych bierze się przede wszystkim stąd, że w języku niemieckim nie ma narzędnika i miejscownika. Przypadki te wyrażane są poprzez mianownik lub przy użyciu odpowiednich przyimków, tak więc mamy tutaj do czynienia ze wspomnianym już brakiem ekwiwalencji w języku docelowym, co wprawdzie nie w każdej sytuacji, ale w wielu przypadkach doprowadza albo do nieprawidłowego, albo do niezręcznego przekładu. Dodatkowa jeszcze specyficzna funkcja narzędnika, sprawiająca trudności nawet polskojęzycznemu interpretatorowi utworu, z jednej strony wzmaga niebezpieczeństwo pomyłek w tłumaczeniu, a z drugiej - wymaga od tłumacza kreatywności, aby nie tylko oddać sens tłumaczonej wypowiedzi, ale by również, w miarę możności, zachować zastosowaną przez autora wersyfikację oraz zamierzoną poetyckość i (często) inność utworu.

Analiza dalszych przykładów Sinielnikoff przynosi kolejne dowody na to, jak trudno tłumaczyć teksty Tuwima. Spójrzmy na wersy z wiersza Dzień: „Dlaczego pod Twoim krzyżem/ Nie leżałem kamieniem od rana” (Tuwim 1968: 249). W tym przypadku pułapką dla tłumacza (tak samo zresztą jak dla odbiorcy polskiego, o czym pisze Sinielnikoff) może stać się znaczenie wyrażenia: „siedzieć - leżeć kamieniem”, ponieważ chodzi tutaj nie o znaczenie: „tak jak kamień”, ale o sens: „nieruchomo, długo, wciąż w tym samym miejscu”. Jeśli zatem przetłumaczyć rzecz dosłownie: warum vor deinem Kreuz/ lag ich nicht wie ein Stein (czyli: „jak kamien”) seit frühem Morgen, wprowadzone zostaje fałszywe znaczenie tego wersu. Zrozumienie i prawidłowy odbiór tego zdania są utrudnione, ponieważ ciężko w nim dopatrzeć się jakiegoś istotnego sensu. Odpowiedniejsze w tym miejscu zdaje się: Warum vor deinem Kreuzl lag ich nicht regungslos seit frühem Morgen (czyli: „bez ruchu od rana”), co oddaje wprawdzie istotę treści, ale z kolei zatraca - możliwą tylko w języku polskim - konstrukcję narzędnikową spełniającą funkcję upoetyczniającą, a także, raczej zamierzoną, korespondencję pomiędzy używaną w polszczyźnie frazą: „leżeć krzyżem” a utworzonym przez poetę wyrażeniem: „leżeć kamieniem”. Wersy stają się wyłącznie poprawną, zrozumiałą wypowiedzią, natomiast jej zamierzona przez autora ekspresja i obrazowanie liryczne owocujące przeżyciem estetycznym zostają utracone.

Z podobną sytuacją mamy do czynienia w wierszu Litery w wersie: „Wisieć kamieniem na szyi" (Tuwim 1968: 15). Ciąży, niepokoi, nie daje spać - w tym znaczeniu użył Tuwim owego zwrotu, łącząc ze sobą dwa, w Polsce dość często używane, związki frazeologiczne: „leżeć na sercu kamieniem” oraz „uwiązać komuś kamień na szyi”. Połączenie to znów powoduje, że odbiorca musi przez chwilę zatrzymać się nad wersami, czas recepcji zostaje wydłużony, dzięki czemu treść informacji zawartej w tekście staje się znacznie bardziej zajmująca. To Tuwimowski sposób na wspomniane już wcześniej odautomatyzowanie odbioru 
tekstu. Niemieckie dosłowne tłumaczenie tego zwrotu: am Hals wie ein Stein hängen jawi się jako semantyczne fiasko - zdanie co prawda pozostaje w pewnym stopniu zrozumiałe dla niemieckojęzycznego odbiorcy, ale nie bywa ono używane ani $\mathrm{w}$ mowie potocznej, ani literackiej w funkcji wypowiedzi frazeologicznej. Spójrzmy na kontekst, w którym umieszczony został interesujący nas wers:

A on nie śpi, bo za nim syczy

Niespokojne przeznaczenie

Literami sekundy liczy

I na szyi wisi kamieniem

Und er schläft nicht, da hinter ihm

Sein unruhiges Schicksal lauert

Und es mit Buchstaben Sekunden zählt

Und es lässt ihm keine Ruhe

[tłum. własne - JD]

To jedna z możliwości translacji, w której ostatni wers, tak kunsztownie zbudowany przez autora, jest w niemieckiej wersji wyjaśniony, przez co jawi się jako uproszczony i traci na sile wyrazu. Można by pokusić się o twierdzenie, że poprawność i jasność tłumaczenia, wynikające z ograniczonych w tym przypadku możliwości zarówno niemieckiej gramatyki, jak i frazeologii, pozbawiły(by) tekst Tuwimowskiego ducha.

I jeszcze jeden przykład, tym razem dotyczący narzędnika określającego podmiot. Oto fragment z wiersza Bagdad, czyli o przysztym poecie:

Zielony sznur jedwabny od elektryczności

Wpełzł w sen gadem, rośliną.

(Tuwim 1968: 23)

Tak jak w dotychczasowych przykładach, konieczne jest i tutaj, w pierwszym rzędzie, poprawne zrozumienie tekstu wyjściowego, co ponownie pozostaje bardziej lub mniej utrudnione ze względu na zastosowane przez Tuwima formy gramatyczne. W podanym przykładzie chodzi o podobieństwo między sznurem a gadem czy rośliną, a nie o porównanie, zatem nie o to, że zielony sznur wpełznął jak gad, czyli nie: wie ein Reptil schleichte sich in den Traum hinein (co narzuca się odruchowo), lecz: einem Reptil, einer Pflanze ähnelde seidene Schnur... Po raz kolejny przekład oddaje wprawdzie treść, ale efektownie wprowadzona do tekstu, rzadko stosowana w języku polskim forma zatraca się w tłumaczeniowym opisie. I w tym przypadku niemożność użycia formy gramatycznej z języka wyjściowego w języku docelowym może doprowadzić do niepoprawnego tłumaczenia lub utraty wartości artystycznych utworu poetyckiego. 
Dla pełnego obrazu przeanalizujmy jeszcze przykład, w którym w utworze Ab urbe condita zastosowany został narzędnik postaci:

Na rogu Ruin i Kresu

Na rogu Ruin i Śmierci,

Co padty sobie w płonące objęcia,

Żegnając się na zawsze, całując płomiennie -

Zjawiła się pękata warszawska babina,

Nieśmiertelna paniusia z chusteczką na głowie.

Postawiła dnem do góry skrzynkę na ruinach

Podparła ją meteorem; jakimś szczątkiem Miasta

I zawołała nieśmiertelnym tonem:

„Do chierbaty, do chierbaty,

Do świeżego ciasta!"

Mogła się zjawić Niobą-Żałobą,

Furią wieszczącą, panią Hiobową,

Rachelą, dzieci swoje płaczącą -

I też by jej uwierzono.

Mogła przyfrunąć wiedźmą na mietle

I też by jej uwierzono.

(Tuwim 1968: 223-224)

Narzędnik postaci (rosyjski narzędnik przeistoczenia) podkreśla w tym tekście ważność pojawienia się wśród ruin ulic jakiejkolwiek postaci, która symbolizuje budzenie się zniszczonego miasta do życia (Sinielnikoff 1968: 68). W związku z tym chodzi nie o sposób, w jaki pojawiła się dana osoba, a o samą osobę i jej obecność. Czyli nie: so wie Niobe (jak Niobe), ale: als Niobe (jako Niobe), in Gestalt Niobe (pod postacią Niobe); czy: als schreiende Furie (jako furia wrzeszcząca), als Hexe auf dem Besen (jako wiedźma na miotle).

Również i w ostatnim przykładzie możliwość zastosowania w języku polskim narzędnika sposobu wymaga aktywnej współpracy odbiorcy, który musi zrozumieć i zdekodować urozmaicone i założone w tekście treści. Podczas translacji na język niemiecki samo poprawne zrozumienie tekstu nie wystarcza, by stworzyć adekwatne tłumaczenie, gdyż brak odpowiedniej formy gramatycznej lub frazy w języku docelowym sprawia, że osiągnięte w ten sposób przez Tuwima uniezwyklenia tekstu muszą, siłą rzeczy, często zostać pominięte i zastąpione innymi, prostszymi formami, co, niestety, często redukuje siłę wypowiedzi poetyckiej i utrudnia przekazanie „inności” tych utworów, do której autor tak konsekwentnie i po mistrzowsku dążył. Ta mistrzowska „inność” i zarazem swoistość Juliana 
Tuwima przewija się, jak już zostało powiedziane, przez całą jego twórczość i wymaga odbiorcy, który potrafi przedzierać się przez zawiłości treści i formy, aby uświadomić sobie i w pełni docenić kunsztowny liryzm wielkiego poety.

Przedstawione przeze mnie problemy wynikające $\mathrm{z}$ tłumaczenia specyficznych form w utworach Tuwima to, naturalnie, tylko niewielka część problematyki związanej z przekładem tekstów tego autora. Nawet jednak tych kilka przykładów, związanych w zasadzie z jednym tylko fenomenem gramatycznym, potwierdza, że teksty tego poety, właśnie ze względu na ich odrębność i oryginalność, tłumaczy się trudno. Nie będzie więc specjalnym zaskoczeniem, że istnieje stosunkowo mało przekładów poezji Tuwima na język niemiecki, co z kolei, niestety, nie przyczynia się do szerzenia na tym obszarze językowym zniuansowanej wiedzy o twórczości tego bardzo popularnego polskiego poety międzywojnia. Przykład Tuwima pokazuje, że deficytowość przy przyswajaniu i poznawania dorobku konkretnego autora $\mathrm{w}$ innym kręgu kulturowym jest niejako wpisana w meandry obcojęzycznych recepcji literackich, ale zarazem też pozostaje silnie uzależniona od stopnia językowego pokomplikowania twórczości, tzn. im mniej paralelne i kompatybilne są struktury i konstrukty w różnych językach, tym mniejsza szansa na zrozumienie swoistego, idiomatycznego sposobu wyrażania wybranego autora. Ta konstatacja oczywiście nie musi przekreślać translacyjnych wysiłków i wyzwań czynionych na rzecz zasymilowania artystycznych osiągnięć jednej kultury w kulturze innej.

\section{BIBLIOGRAFIA}

Doschek Jolanta. 2017. Czy trudno jest ttumaczyć teksty Tuwima? W: Julian Tuwim. Tradycja, recepcja, perspektywy badawcze. Red. Ewa Gorlewska, Monika Jurkowska, Krzysztof Korotkich. Białystok: Instytut Filologii Polskiej Wydział Filologiczny Uniwersytet w Białymstoku. ISSN: 2450-1913. ISBN: 978-83-86064-470-2. S. 315-323.

Głowiński Michał. 1962. Poetyka Tuwima a polska tradycja literacka. Warszawa: PIW. Jakubowski Jan Zygmunt. 1954. O poezji Juliana Tuwima i Konstantego Gatczyńskiego. „Polonistyka”, nr 1. ISSN: 0551-3707. S. 1-22.

Kußmaul Paul. 2000. Kreatives Übersetzen. Tübingen: Stauffenburg Verlag. ISBN: 978-38-6057-249-8.

Paepcke Fritz. 1989. Der Übersetzer im Dienste der Technik und als Wegbereiter des Dichters. „MBÜ. Mitteilungsblatt für Dolmetscher und Übersetzer”, nr 5. ISSN: 1618-5595. S. $1-10$.

Sinielnikoff Roxana. 1968. Ze studiów nad językiem Juliana Tuwima. Wrocław: Ossolineum.

Tuwim Julian. 1968. Dzieta. T. 1. Warszawa: Czytelnik. 
Jolanta Doschek

\title{
THE RECEPTION OF JULIAN TUWIM'S WORKS \\ IN GERMAN-SPEAKING COUNTRIES. A FEW NOTES ON TRANSLATION PROBLEMS
}

\begin{abstract}
(abstract)
The article responds to the need for a more comprehensive research on the reception and translation of Julian Tuwim's diverse and innovative oeuvre outside Poland. More specifically, it discusses the reception of Julian Tuwim's works among German-speaking readers. The author examines selected problems with translating Tuwim's poetry into German, which are related to the structure and syntax of the poems. In particular, the article focuses on the creative use of declensional forms, which is hard to convey in German due to the fact that it lacks instrumental forms of nouns.
\end{abstract}

KEY WORDS

Julian Tuwim; poetry; translation; reception in German-speaking countries 